Florida International University FIU Digital Commons

$1-14-2014$

\title{
Bleaching To Reach: Skin Bleaching as a Performance of Embodied Resistance in Jamaican Dancehall Culture
}

Treviene A. Harris

tharr006@fiu.edu

DOI: $10.25148 /$ etd.FI14040829

Follow this and additional works at: https://digitalcommons.fiu.edu/etd

Part of the Community-Based Research Commons, Critical and Cultural Studies Commons, Dance Commons, Esthetics Commons, Ethnomusicology Commons, Inequality and Stratification Commons, Other English Language and Literature Commons, Other International and Area Studies Commons, Other Languages, Societies, and Cultures Commons, Performance Studies Commons,

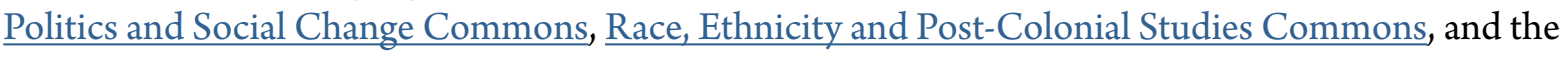
Social and Cultural Anthropology Commons

\section{Recommended Citation}

Harris, Treviene A., "Bleaching To Reach: Skin Bleaching as a Performance of Embodied Resistance in Jamaican Dancehall Culture" (2014). FIU Electronic Theses and Dissertations. 1129.

https://digitalcommons.fiu.edu/etd/1129 


\title{
FLORIDA INTERNATIONAL UNIVERSITY
}

Miami, Florida

\section{BLEACHING TO REACH: SKIN BLEACHING AS A PERFORMANCE OF EMBODIED RESISTANCE IN JAMAICAN DANCEHALL CULTURE}

\author{
A thesis submitted in partial fulfillment of the \\ requirements for the degree of \\ MASTER OF ARTS \\ in \\ ENGLISH \\ by
}

Treviene A. Harris 
To: Dean Kenneth G. Furton

College of Arts and Sciences

This thesis, written by Treviene A. Harris, and entitled Bleaching to Reach: Skin Bleaching as a Performance of Embodied Resistance in Jamaican Dancehall Culture, having been approved in respect to style and intellectual content, is referred to you for judgment.

We have read this thesis and recommend that it be approved.

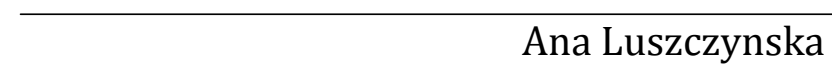

Steven Blevins

Heather Russell, Major Professor

Date of Defense: January 14, 2014

The thesis of Treviene A. Harris is approved.

\begin{tabular}{r} 
Dean Kenneth G. Furton \\
College of Arts and Sciences \\
\hline Dean Lakshmi N. Reddi \\
University Graduate School
\end{tabular}

Florida International University, 2014 


\section{ACKNOWLEDGMENTS}

I wish to thank my thesis committee, Drs. Heather Russell, Ana Luszczynska and Steven Blevins, for the motivation, confidence, encouragement, guidance and support given me throughout this arduous process. With special thanks to Dr. Russell for empowering me to make the big decisions regarding the direction of this thesis, and for making this process as pain-free as possible. I am also immensely grateful to Dr. Donna Hope at the University of the West Indies, Mona, for sharing with me her valuable time to sit and share ideas, but more importantly for her work that gave me much needed direction for this project. To my sister, Jhana Harris, thanks for working tirelessly to make contacts on my behalf that contributed to what I consider to be the most important part of this thesis: the interviews. My most sincere thanks to Indo Byfield and Orlando (King) Patterson for coming through at the eleventh hour with much needed assistance. Finally, big up and bless up to the Burgher Gully massive; you know who you are. I thank you each for your time, insights and candor. But most of all, thank you for trusting my ear and my pen to do work that I hope is on your individual and collective behalves. 


\begin{abstract}
OF THE THESIS
BLEACHING TO REACH: SKIN BLEACHING AS A PERFORMANCE OF EMBODIED RESISTANCE IN JAMAICAN DANCEHALL CULTURE
\end{abstract}

by

Treviene A. Harris

Florida International University, 2014

Miami, Florida

\title{
Professor Heather Russell, Major Professor
}

This thesis examines how skin bleaching can be understood within the cultural context of Jamaican dancehall. I argue that as a cultural practice, skin bleaching can be viewed as a critique of the concomitant structural inequalities precipitated by colorism, which is a by-product of racism. In proposing skin bleaching as a queer performance of color, I attempt to illustrate the manner in which the lightening of the skin exposes the instability of racism and colorism as socially constructed, discursive regimes. If race and skin color are biological and embodied facts dictated by social reality, then bodies, which are racially marked and colored subjects, can be used to project counter discourses that challenge these specific regimes. The space of discursive limit imposed on the racialized or colored body-subject is a space from which critiques of dominant discourses can be projected, and bleaching does precisely that. I conclude therefore, that skin bleaching is performed resistance which challenges the dominating discourses on race by first destabilizing the notion that skin color is an immutable biological fact, and second by contesting subsequent discourses that are contingent on the facts of color and race. 


\section{TABLE OF CONTENTS}

CHAPTER

PAGE

Prologue

Part I. Sup'n Inna Sup'n The Signifying Re ..........................................................

Part II. Yah So; Deh So: The Inoperative Border .......................................................11

Part III. Look Pon We: The Communicative Body ………………………..................33

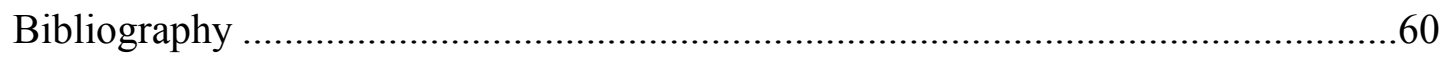




\section{Prologue}

At the time I was growing up in Jamaica, Bob Marley was fast approaching the peak of his posthumous stardom. His music provided a proverbial soundtrack to our lives- past and present- and became part of a tradition of elaborating a particular social consciousness that helped to define Jamaica as a nation, and reggae music internationally. So popular was Marley's music that even at an early age I recall mimicking words to his songs long before I knew the actual words, let alone what they meant. When hearing his hit "Redemption Song," being cued by the immediately recognizable, stirringly isolated, vibrating and resonant opening chords, I would sing with profound sincerity and feeling: "Oh, pirate yet day rabbi/ Sold eye to the merchant ship..." The correct lyrics, of course, are: "Old pirates, yes, they rob I/ Sold I to the merchant ships...." This song in which Marley alludes to the Atlantic slave trade, speaks to the collective and strangely unifying Black history of displacement and dispersal. Redemption songs, and by extension redemptive music as a cultural idiom of the Black diaspora was one way that we, as a people, are able to articulate, elaborate, and come to terms with a history of oppression and marginalization.

Another well-known Marley song I can recollect that explicitly engages the politics of colonialism, race, and social inequality is "War." What might be lesser known, however, is that the lyrics of this song are part of a speech given on October 4, 1963 by His Imperial Majesty, Emperor Haile Selassie, at the United Nations General Assembly 
in New York, months after the founding of the Organization for African Unity. ${ }^{1}$ The excerpt from the speech used in, and popularized by, Marley's song reads:

Until the philosophy, which holds one race superior and another inferior is finally and permanently discredited and abandoned, everywhere is war. And until there are no longer first-class and second-class citizens of any nation, until the color of a man's skin is of no more significance than the color of his eyes, and until the basic human rights are equally guaranteed to all without regard to race, there is war. And until that day, the dream of lasting peace, world citizenship, rule of international morality, will remain but a fleeting illusion to be pursued, but never attained.

Here, Selassie was denouncing the way sustained inequalities wrought by an institutionalized belief system that "African-ness," "blackness," via skin color, are markers of inferiority and consequently justification for imposed social limitations. In other words, Selassie avers that skin color, or more precisely being black, should be no more influential than eye color in determining the basic human rights that are afforded to an embodied subject, but further, and what I believe is the crux of Selassie's assertion is that as a matter of morality and human(e) citizenship, black personhood must be regarded as equal to non-black personhood.

\footnotetext{
${ }^{1}$ The Organization for African Unity (OAU) was formed in 1963 with the intention of establishing a collective voice for united African states as a means to pursue and secure their long-term economic and political well-being.
} 
Given this interpretation, I found it curious that some fifty years after Selassie's speech, popular Jamaican dancehall ${ }^{2}$ deejay, Vybz Kartel, would invoke both the rebellious soul of Marley, and Selassie's words during a lecture in which he discussed the practice of skin bleaching in dancehall culture (in the aftermath of his having launched a line of "cake-soap" bleaching products, used by himself personally, as evident by his increasingly lightening skin). Taking the line "until the color of a man's skin is of no more significance as the color of his eyes" outside the context of the entire speech, Kartel intimated that skin color was as benign as eye color and therefore was no real indication of "blackness" as a sociocultural marker. I was fascinated by his proposition. What Kartel appeared to be saying was that in dancehall culture, skin bleaching represented the articulation of a new, or modern, "blackness" wherein skin color held no real value, or rather was devalued in the scopic economy of race and racism in a colorist ${ }^{3}$ society like Jamaica's.

To this end, my thesis is interested in exploring how skin bleaching as a practice in dancehall culture can be read as a renewed fight against the colonial "one drop" "ism and schism", ${ }^{4}$ and how it challenges the way we perceive the fact of biological

\footnotetext{
${ }^{2}$ Dancehall refers to a specific and unique cultural performance that originated in the urban ghettos of Kingston, Jamaica. Norman Stolzoff identifies dancehall as "the most potent form of popular culture in Jamaica." Throughout this thesis I use the term "dancehall" to mean the physical space of entertainment, the symbolic space of release and transformation, and as a metonymy for cultural practices originating from a socio-economically marginalized urban population in Jamaica.

3 "Colorism" is a term coined by Alice Walker in her 1983 essay "In Search of Our Mothers' Gardens," which defines colorism as "prejudicial or preferential treatment of same-race people based solely on color."

4 "One drop" in my usage alludes to the colonial "one drop" rule, whereby someone who had even one drop of black blood would be conclusively racially defined as black. However, in his song "One Drop," Bob Marley sings about music as a means of resisting and fighting against "ism and schism," which is a Rastafarian expression meaning an oppressive system founded on what Marley identifies as the "devil's philosophy."
} 
"blackness," while troubling the social institution of race that idealizes skin color.

Additionally, if I may take the same liberty as Vybz Kartel and isolate Selassie's words, my thesis dwells on the social meaning and implications, the possibilities inherent in the pursuit rather than the attainment of "until" that Haile Selassie lays out as a challenge. Past is prologue. A suh di ting set. 
Bleaching to Reach: Skin Bleaching as a Performance of Embodied Resistance in

Jamaican Dancehall Culture

\section{Part I. Sup'n Inna Sup'n: The Signifying "Re"}

"By engaging, appropriating, and resignifying dominant Euro-American cultural...practices, poor and working-class Jamaicans have aspired to a modernity of their own making within the context of their own history. Rather than seeing this engagement as false consciousness, assimilation or acquiescence to the hegemony of neoliberal capitalist globalization, then, we must see it as laying claim to an as yet unfulfilled promise."

Deborah A. Thomas, Modern Blackness

Outside of the specific cultural context of dancehall, varied hermeneutic approaches have been used to explore the practice of skin bleaching in general. Mainly sociological and psychological studies have sought to align skin bleaching with the Fanonion "self-hate thesis" where colonized subjects harbor internalized inferiority predicated upon negative associations attributable to having dark skin, and resulting in the phenomenon of colorism. The self-hate, low self-esteem, or identity crisis discourses suggest that the colonial enterprise is wholly responsible for the dissemination of Eurocentric aesthetic ideals that authorize notions of beauty, privileging European physical features while simultaneously devaluing and negating blackness, dark skin and "typical" black features. Christopher Charles cites the landmark Clarke \& Clarke "doll" experiment conducted in 1947 as a watershed moment that propagated and propelled the self-hate theory. ${ }^{5}$ Beyond the mere physicality of blackness, however, the self-hate theory elucidates the series of associations, rooted in negative differences, which only begin

\footnotetext{
${ }^{5}$ The Clarke \& Clarke doll experiment was used to study children's attitudes towards race. In the experiment black and white children were given two dolls, identical except that one doll was black and the other was white, and asked to select which doll they preferred. All the children's responses showed an overwhelming preference for the white doll. This led Clark \& Clark to conclude that the black children harbored feelings of rejection and self-hate toward their own race.
} 
with skin color and can extend to judgments of beauty, academic capabilities and criminal tendencies. In other words, because of the negative associations of "blackness," generally and intra-racially, persons of African descent can and do internalize the idea that they are less attractive, less intellectually capable, and more prone to criminality, which leads to a condition of self-hatred. The persistence of colorism, or "pigmentocracy," Margaret Hunter argues, is sustained by a belief system that aligns blackness or dark skin with "savagery, irrationality, ugliness and inferiority;" attributes codified as antithetical to possessing lighter complected skin ("The Persistent Problem" 238).

In postcolonial societies like Jamaica, where there is colorism, but also an unmistakable sense of black pride, there is increasing anxiety over the epidemic of the "bleaching syndrome." Responses to the bleaching syndrome have been varied, but the perceived explosion in skin lightening has led contemporary scholars and critics to question, and in some cases outright reject, the self-hate thesis as the sole explanation for skin bleaching. For instance, Charles calls for more diversified analyses considering the "different histories, cultures, socialization practices, personalities, individual experiences and belief systems" of skin bleachers ("Liberating Skin Bleachers" 87). Moreover, Winnifred Browne-Glaude argues that the self-hate theory not only pathologizes skin bleachers as deviant, but also reifies the hegemonic order that fixes skin color, and therefore blackness, as an irrefutable biological fact within a color hierarchy. This colorist system of regulating bodies, Browne-Glaude notes specifically in reference to Jamaica, has social and political ends that are aimed at maintaining a status quo marked by brown privilege and bourgeoisie respectability, and which fails to address social and 
economic inequalities that disproportionately affect the class of people who are typically identified as bleachers (37). The failure of political and social interventions to alleviate material causes of socio-economic disenfranchisement has led to a phenomenon where skin color is leveraged as "symbolic capital" by the poorer black working class who may bleach (Glenn 282). Therefore, contrary to being "vanity and [a] misguided relic of the colonial past," it has been argued that the practice of skin bleaching persists, and is indeed increasing, as a result of the widening gaps between social classes (Glenn 282). Having lighter skin then, has become conflated with sophistication, social-mobility, success and the resulting financial and economic well-being (Glenn 282).

Still, another analysis situates bleaching within the context of globalization and mass marketing via which trans-national, neo-colonial ideologies continue to disseminate old belief systems pertaining to Eurocentric ideals of beauty. Citing Kathy Davis, Hunter additionally claims, "It is now normative in many societies to view the body as a 'work in progress.' People no longer view the human body as a 'given,' but increasingly see it as changeable" ("Buying Racial Capital" 146). In other words, the global proliferation of media images which privilege specific types of bodies and beauty drives the global competition among cosmetics companies for increased market share, when combined with the normalizing of cosmetic procedures, have contributed to skin bleaching being seen as merely sign of modernity or keeping up appearances. As a result, even if we grant the ideologies that inform decisions to bleach the skin are firmly rooted in racism and colorism, it seems clear that self-hate is emphatically not the singular motivation.

Beyond the social and psychological, cultural critics have also intervened in the skin bleaching discussion attempting to argue yet another rationale which rejects the 
singularity and constriction of the self-hate/low self-esteem thesis. In this complex debate, Donna Hope, most notably, has added yet another concentric circle of meaning. ${ }^{6}$ With regard to Jamaican dancehall music and culture, Hope decodes skin bleaching as representative of "contemporary modes of fashion and ungendered rites of beauty" in the tradition of the transgressive performative signifying practices, which have come to define Jamaican dancehall culture (Man Vibes 142). Although Hope focuses on skin bleaching as a previously feminizing practice that is now among the "transgressive rituals and fashion choices" appropriated by dancehall masculinities gesturing toward an ungendered aesthetic, her concepts of "re-casting," "re-fashioning," and "re-positioning" prove particularly generative (Man Vibes 124). The prefix "re" implies a "doing over" toward a new way of seeing, effectively an undoing of an old way to arrive at a finished and completed new way of doing or seeing. For Hope, these transgressive acts foment the process of un-gendering, effectively challenging prescriptive epistemologies reinforced by dominating discourses on feminine and masculine ideals. While Hope's research foregrounds the possibilities of new kinds of gender performance, in my discussion of skin bleaching I would rather like to focus on what lies in-between the process of embodied signification. In other words, what happens before the arrival at a new signification? Or, how might we elaborate the practice of skin bleaching within the interstice of the signifying "re?"

Consequently, I wish to push Hope's theory of un-gendering further, and contend rather that skin bleaching might be interpreted as one of many queer performative acts

\footnotetext{
${ }^{6}$ In Representations: Cultural Representations and Signifying Practices, Stuart Hall uses the term "circles of meaning" to explain the way in which cultural practices are usually multi-layered, and therefore difficult to attribute to one specific cause or event.
} 
within dancehall culture that stress with a view to destabilize various inequitable larger social structures. In other words, the signifying "re" metaphorizes the queering of identity with the fluid space of the dancehall. Here, I am thinking specifically of Judith Butler's appropriation and theorization of "queer." For Butler, "queerness," or being queer, fearlessly challenges the "validity and consistency" of discursively constituted identities ("From Gender Trouble" 2543). Butler therefore reads queerness as a means by which fixed identity constructions, or other social constructs are destabilized. Accordingly, Nadia Ellis recognizes the "intrigue and possibilities of a queer dancehall hermeneutic" (9). A queer methodology, Ellis contends, has the potential to "open a conversation about gender and sexuality in Jamaican popular culture that registers even as it exceeds the confines of discussions of homophobia that have so far dominated" (9). While my thesis, unlike Ellis's work, does not focus on performances of gender and sexuality within the cultural context of dancehall, her proposal to integrate a queer hermeneutic within cultural readings of dancehall creates the possibility of stimulating tessellated conversations concerning how other modes of performing a transgressive social identity might be understood within "a network of social relations with the power to confirm or to disallow that identity..." (9-10). When reading dancehall culture then, aside from gender and sexuality politics, "queer" may be theorized as analogous with the process of resignification through performed identities, or what Sara Ahmed calls a "turn toward," as in turning away from what is considered allowable (25).

Additionally, my analysis of the performativity of bleaching within dancehall culture draws on Frank's notion of "the communicative" social body, which he argues, is a social body that has the potential to engage in dialogue and subsequent argumentation 
with existing social structures by projecting embodied narratives of experiences (Shilling 84). The queered/ing communicative body engaged in the act of skin bleaching performs an impersonation of color- effectively undermining a fixed social construct- fully cognizant of the ways in which, as Butler claims, all impersonations are impersonations passing as real ("From Gender Trouble" 2541). In other words, these performances are not concerned with establishing a new real, but show up the un-realness of the real. ${ }^{7}$ Thus, I employ Butler's term "passing" in its doubly suggestive sense in this discussion of skin color, as it alludes to both the act of passing- as in the deceptive performance of a skin color- and the construction of identity in general, which Butler asserts is an act of repeated impersonations that tries to pass or fix identities as stable constructs.

\footnotetext{
${ }^{7}$ In Bodies that Matter, Judith Butler argues that the "real" is a production of language and by extension discourse. As such it remains an unstable fact that fails to "finally and fully" identify that which is refers to.
} 


\section{'Part II: Yah So; Deh So: The Inoperative Border \\ "The study of Jamaican Dancehall is stubbornly rooted in a politics of place..." \\ Carolyn Cooper, Sound Clash}

It is widely accepted among cultural studies theorists that, in Jamaica, dancehall identities are negotiated with the intention of challenging institutionalized notions of cultural respectability. In contexts of music, lyrics, and fashion, practitioners who operate within the "countercultural space of the dancehall" consistently challenge and provoke the limits of traditionally perceived acceptable and respectable behavior and expression (Thomas 7). Since dancehall is a counter cultural phenomenon enacting a culture of resistance, it is vitally important to situate geo-politically and symbolically, the places/spaces from which it emerges within the larger Jamaican social structure.

The vast majority of Jamaica's population, an estimated ninety-seven percent, is of African descent, and Hope further clarifies that "the greater percentage of Jamaica's very poor and chronically underemployed is darker-skinned or black" (Inna De Dancehall 9). As the largest metropolitan city in the Anglophone Caribbean, Kingston, Jamaica's capital city is the principal urban dwelling space or inner city ghetto where dancehall music and subsequent culture took shape. Considering that thirty to forty-five percent of Kingston's population lives in these urbanized, overcrowded inner city housing schemes ${ }^{8}$ or ghettos, it can be concluded that the majority of those who are contained within those structures are black/African Jamaicans. Norman Stolzoff uses the

\footnotetext{
${ }^{8}$ The word "scheme" is a Jamaican urban argot that can refer to these urban areas of government subsidized housing developments- or housing schemes- that have been set-aside for generally low-income citizens. Due to the combination of low-income, high crime factors, the idea of the scheme has come to represent a clearly demarcated physical and symbolic space that defines its inhabitants as socioeconomically "other."
} 
geographical metaphor "Downtown" to refer to these schemes of inner-city slum areas and poor rural districts highly populated by "darker-skinned lower classes" (231). In Kingston, specifically these socially excluded inner city communities are typically located outside centers of commerce and wealth; there are few wealth-generating, formal industries or commercial activities within these communities, mainly as a result of high crime common to these areas. Residents frequently must travel outside of the geographical confines of their communities to access socially desirable jobs or schooling that may portend material upward mobility; for these opportunities, per Stolzoff's distinction, they must venture "Uptown." The discussion of dancehall as originating from the spaces of "downtown" emphasizes how the idea of "downtown" and "uptown" as terms no longer simply refer to geographic spaces, but have taken on inherent social, political and cultural meanings.

Hope and Nadi Edwards both identify these inner-city slums as sites of Dis/place/ment. Hope uses the term "dis" in two ways: the Jamaican expression "dis" is the equivalent of the Standard English "this," and the urban vernacular expression "dis" as an abbreviation of "disrespect." In so doing, Hope draws attention to the "this place"the space of inner city poverty- which is a "dis" place where the lower-class are dispossessed, dis-respected and dis-regarded by the dis-avowal and subsequent disassociation from the rest of society. In fact, a 2008 Amnesty International report focused on public safety, the alleviation of violence, and the protection of human rights in these marginalized urban communities, was critical of the state's failure "to effectively provide human security to... people living in poverty in inner-city communities" and implored that the Jamaican government to "show political will" in combatting politically induced 
violence, and improve living conditions for citizens of these urban areas ("Let Them Kill Each Other" 1, 42). The report also expressed the need to eliminate various human rights violations that invariably occur when the state tries to regulate, police, and/or secure these spaces.

Edwards, much like Hope, reads these urban spaces as sites of "bare life." By extending Agamben's theorizing of the "biopolitical paradigm of the camp," Edwards imagines these spaces in the city of Kingston as camps of dis/place/ment (1). For Edwards, "Dis" alludes to "the overwhelming negative ethos of time and place," and he adds, "Dis is the Roman god of the underworld, and also the name of the Devil both in the subterranean city containing the lower circles of hell..."(5). In other words, the bare life circumstances that exist in Edwards' camps of Dis/place/ment are emblematic of a hellish, dystopic reality fostered by the harsh socio-economic conditions that this literal and figurative fringe population must endure. These bare urban spaces bear witness to exorbitant levels of crime, where between 1970 and 2005 there was a murder rate increase from 8.1 per 100,000 to 64 per 100,000. Further, between 1998 and 2005, of the 8993 murders committed nationwide, $76 \%$ occurred in the Kingston Metropolitan Area (Gray 3). Sherrian Gray concludes that the increasing rates in violent crimes in these areas are exacerbated by "lack of employment, absence of employable skills by job seekers, inadequate housing facilities, gang violence, illegal drug trade, inadequate social services and inaccessibility to basic utilities"(5). All these factors have come to define the precariousness of inner-city life in Kingston. Indeed, that section of Gray's report was aptly titled "Why Kingston is a good case study for crime in Jamaica." 
Residents of such communities are all too aware of their positions of social, political and economic dis/place/ment, and this cognition is what impels performances of resistance and revolt. For example, popular dancehall deejay and self-proclaimed "poor people's governor," Bounty Killer, voices the frustrations on behalf of ghetto dwellers in his song "Fed Up," when he sings:

Well poor people fed up to how yuh system sheg up

Yuh issue gun fi wi pickney bus'

Poor people fed up to how yuh system sheg up

Well every day the ghetto yout's a dead up

(Well poor people are fed up with your unfair system

You have issued guns for our children to use

Poor people are fed up with your unfair system

Well every day ghetto youth are dying)

Mi ask di leader him a di arranger

Fi mek poor people surroun' by danger

Fly an' di roach an' giant mosquita

Sewage water weh fill wid pure bacteria

Unno ever tek a look dung inna di Riverton area?

Bactu and Seaview? Waterhouse, Kentire?

Long time di MP him nuh come near yah,

And di nedda one weh claim seh she a councilor 
Rob seventy five percent an' gi wi quarter

Conquer de lan' nuh waan fi gi wi a acre

(I ask the leader, who is [also] the arranger

Who has caused poor people to be surrounded by danger

Fly and roach and giant mosquito

Sewage water that is filled with bacteria

Have you ever taken a look over [in] the Riverton area?

Bactu and Seaview? Waterhouse and Kentire?

It has been a long time since the MP has not been here

And the other one who claims that she is a councilor

They have robbed seventy five percent and left us with a quarter

Conquered the land and do not want to give us one acre)

In the song, Killer lyrically confronts negligent and corrupt policy makers, "di leader[s]," who have stood idly by while deplorable and inhumane living conditions persist in the urban ghetto communities. He mentions by name communities such as Riverton City, whose close proximity to the largest landfill in Jamaica symbolizes an unmanageable wasteland of neglect. Other communities such as Seaview Gardens, Waterhouse, Tivoli Gardens and Mountain View Avenue, much like Riverton City, are heavily policed, notorious political strong holds and sites of wanton poverty, crime and violence. But perhaps the most significant grouse that Killer launches is the absence of material ownership that marks these spaces. His hostility is leveled squarely at "di arranger[s]" who have conquered the land and claimed seventy-five percent ownership of property, and by extension have robbed the poor black lower class of the opportunity to 
carve out a humane material existence. This condition recalls the historically forced racial inequities precipitated by the British colonial enterprise, and signals their continuation in the contemporary lives of working class black people. The unequal, oppressive system that Killer rails against is one where the predominantly black lower and poorer class, due to their lack of economic viability, is marginalized and confined within borders instituted by the wealthier white and brown owning class comprised of "large scale propertyowning capitalists and top-level technocrats, bureaucrats and politicians" (Inna Di Dancehall 6). The Jamaican power elite have schemed, planned and executed a system of physical borders and confinements that define social spaces and classes, and which work toward reinforcing the politics of separation, exclusion and limited mobility as mechanisms of control over the poor black working-class.

The realities of borders and confinement that underpin the color/class relationships in Jamaican society simultaneously gives way to the creation of a discursive symbolic and geo-political space that can be used theoretically to read the modes of cultural production that is dancehall, and indeed the creation of dancehall as a culture itself. Hope and Stolzoff articulate the emergence of dancehall as a resistive performance culture in contestation of, or opposition to institutionalized socio-economic, sociopolitical and cultural borders. Hope claims that dancehall evolved from

$[T]$ he cultural dichotomy...that resulted from slavery and creole society...[that] persists in contemporary Jamaica with 'high culture' of the predominantly brown or lighter-skinned middle educated middle class being polarized against the 'low culture' of the predominantly black or darker-skinned masses of the inner cities and lower classes (Inna Di Dancehall 9). 
The struggle and confrontation that Hope describes occurs symbolically as a color/class/culture conflict, which happens to be performed in the living spaces where these oppositional classes reside. In other words, both upper and lower class produce and reproduce their respective and conflicting idioms of culture within their respective social domains. Stolzoff further suggests that,

Jamaicans themselves tend to group the range of ideological views about dancehall into two groups: the uptown critics and downtown defenders...this ideal split... is between the uptown and downtown is a good indicator of the battle line that people bring to dancehall as a social institution (230).

Although, as stated earlier, Stolzoff points out that the classifications of uptown and downtown operate metaphorically rather than exclusively spatially or geographically, the semiotic implications of the word "uptown" when contrasted with "downtown" underscore a series of associations that reinforce borders and boundaries allied with dichotomized and longstanding racialized notions of inferiority and superiority. Uptown implies affluence, education, capital- both culturally and otherwise- whereas downtown does not. In fact, Stolzoff goes on to say, "for lighter-skinned middle and upper-class, glossed as uptown people, opposition to dancehall is galvanized by their sense of cultural superiority" (6). Dancehall, then, as culture functions as resistance against the dictates of the white/ brown upper-class who presume to be the final authority on not only what defines culture, but further, who gets to represent or perform approved culture, and where and how those representations of approved culture can be performed. Also, the uses of geographic descriptors stress the importance of location and "situatedness" in terms of 
bordered and boundaried spaces as a means of sociocultural and sociopolitical containment.

As a consequence, dancehall culture as a form of resistance against institutionally approved culture defined by elite standards must, by necessity, engage in "performance practices of opposition" (Stolzoff 217). These performances occur where difference or competing forms of expression collide, that is to say, where differences meet and resist each other. In other words, these performances take place when "downtown" confronts "uptown," or where low culture contests high, at a site that Mary Louise Pratt defines as a "contact zone," where cultures meet and grapple with each other in highly asymmetrical power relations. In extending Stolzoff's concept of dancehall as an expression of confrontation between "uptown" and "downtown," Gaston Bachelard's theory of the dialectics of outside and inside proves useful. Bachelard acknowledges that "beyond what is expressed by formal opposition, lie alienation and hostility between the two"(217). In other words, between performance practices within and without a defined border, the need for one to supersede the other will always be marked by tension. Therefore "uptown," from the position of an assumed cultural superiority will continue to attempt a reformation of "downtown" toward what "uptown" deems acceptable. On one hand, there is anxiety among those who need to maintain the border (uptown/downtown), and on the other hand, the recognition of seething rebellion of those who struggle to resist and even subvert the limits and limitations imposed upon them. Thus, Bachelard concludes as a result of this persisting underlying tension "opposition is incapable of remaining calm" (217). Arguably, the absence of calm between these opposing social, economic and cultural forces characterized by the dialectics of uptown and downtown, low and high 
culture, is what Hope alludes to when she concludes that dancehall music and culture were borne out of the pressures experienced by the lower class who felt and were excluded from and unrepresented by the existing and dominant forms of cultural expressions (Inna Di Dancehall 8-9).

In dancehall, the tense, "charged cultural borders" that separate and define the geographic and symbolic spaces of uptown/downtown provokes other discursive conflicts (Stolzoff 6). These conflicts present themselves, for example, in the dialectics of here and there, normative and non-normative, formal and informal, or placement and dis/placement, much in the same way that Bachelard understands the tension between outside and inside. Bachelard proposes that the dialectics of division which oppositional concepts such as outside and inside create, is a division which "has the sharpness of yes and no which decides everything" (211). The implication here is: that which is situated, or placed, inside and outside of specific borders necessarily signify what is permissible and permitted (the yes and therefore implicit no) per the dominating discourse. With regards to dancehall culture, Hope styles the dialectic of division occurring between dancehall and "high society" as a discourse of "wi vs. dem" (we versus them, or us versus them) (Inna Di Dancehall 129). She further elaborates that the "discourse of 'wi vs. dem' serves as revolutionary purpose in awakening sites of power that are not oriented around traditional prescribed sites" (Inna Di Dancehall 129). It is particularly instructive that Hope chooses to express this division using the vernacular Jamaican language associated with the black lower-class and not the traditional grammatically correct expression "us and them" which would be used by the formally educated middle class. By using the equivalent of the first-person plural "we," Hope lays bare that the act of separation and 
discursive distinguishing is a unified and decisive power-play initiated by the lower-class. That is to say, as a collective, theirs is a re-possessing of agency, pride and identity in utilizing anti-elitist language; the black working-class cultural artists want to separate themselves as re-clamation of identity on their own terms.

Additionally, the use of the word "versus" emphasizes a competing and defiant nature of this re-negotiation of identity and personhood, which runs counter to how the dominating class would seek to identify and classify the lower-class. The poor black working-class as definers of themselves and designators of their own borders, have the final- and indeed only- authority to determine what is or is not permissible within their designated spaces. As a consequence, there is an inherent threat, tension, and an absence of calm, in the resulting ambiguity that surrounds the question of who is an insider or outsider. The appropriation of "wi" and "dem," mediates the relations of power at least discursively, and now there emerges a re-articulation of the "subject" and "other" relationship; the previously "othered" black lower class are re-casting, re-fashioning and re-positioning themselves as autonomous, empowered subjects. As such, the poor black lower-class who have been confined to the outer limits of acceptable society and culture have become the insiders who can now authorize their own cultural expressions outside of the limitations imposed by official discourses. The use of "versus," signals a challenge to the established markers of legitimacy; this challenge effectively causes the traditional relations of power become unfixed, dynamic and dialectically engaged.

The grab at cultural legitimacy by the black Jamaican lower-class across the border is perceived as menacing by the upper-class, and creates a upheaval or disturbance, which Stolzoff contends, causes "the dominant class [to] see dancehall as a 
threat to their cultural leadership and to society as a whole" (230). ${ }^{9}$ Dancehall culture seemingly jeopardizes not only standards upheld by the upper-class guardians of high culture, who value traditional Eurocentric-aligned forms of cultural expression, ${ }^{10}$ but also the rigidly hierarchized social structure whose continuity and stability can only be sustained by steadfastly- and anxiously- held boundaries. The volatility inherent to these sociocultural frames of containment, and their concomitant vulnerability, Carolyn Cooper argues, renders borders as sites of contestation, or what she theorizes as sites of "border clash." Cooper avers that when "taken out of the immediate context of the dancehall event, the concept of 'border clash' has resonance in defining a broader range of conflicts in Jamaican society" (40). For Cooper, the "border clash" encapsulates multivalent dissonances that occur between the socio-economically exiled black lower-class and the lighter-skinned self-proclaimed guardians of culture. Therefore, it is easy to understand why at these borders, manageability, or lack thereof, is a source of anxiety for those who it is in their best interest to fix clearly defined and cordoned off spaces. Rather than celebrate or acknowledge the rights of the cultural "other" to engage in their own forms of self-expression, these anxieties signal crisis at the cultural border (Thomas 11).

To illustrate the problematics and limitations when speaking on the manageability of borders, in her introduction to Frames of War: When Is Life Grievable, Butler deploys the concept of framing, or frames. For Butler, the frame or framing can be used a means

\footnotetext{
${ }^{9}$ My emphasis.

${ }^{10}$ Trinidadian Soca music and carnival are notable exceptions to this conclusion. Although Soca and carnival are forms of cultural expressions that are decidedly non-Eurocentric as they have emerged from marginalized classes, they are appreciated by Jamaicans who could be considered upper-class or belonging to high society. The assumption is the ability to travel abroad to Trinidad for carnival and being able to experience alternate forms of culture demonstrates a type of privilege that differentiates between social classes.
} 
of discursively containing, securing or fixing. In her way of thinking, if frames by extension create borders, then the notion of framing is not only a matter of discerning what is contained or fixed (secured) in the frame, but conversely calls attention to external forces working anxiously to maintain the frame. At sites or borders of conflict and confrontation the framer situated outside is compelled by a state of ever-vigilance in order to ensure that the borders of the frame are not compromised. As such, various attempts and re-framing, re-accommodating and re-zoning must perpetually occur. Further, these instances of re-adjustments may be understood to be re-iterations of the original frame which can never accurately replicate the original frame or boundaries. ${ }^{11}$ Butler concludes then, that frames eventually become untenable and unmanageable precisely because of the anxiety that attends the efforts fix them, and further that in these instances of re-framing slippages through the cracks of the symbolic frame will and do occur. Butler's theory of frames helps to clarify how and why Stolzoff, Hope and Sonjah Stanley- Niaah describe dancehall music and culture as a means or a site for alleviating the pressure from the imposed frames of socio-economic confinement. Each critic successively reads dancehall as "a place of release," "a safety valve to release pent up frustration," and "a release and...opportunity...to escape quotidian social and economic challenges" (Stolzoff 206; Inna Di Dancehall, Hope 9; Niaah 21). These insights situate dancehall expression as resisting the imposed frames or escaping from within the restricting borders delineated by the upper-class guardians of high culture.

\footnotetext{
${ }^{11}$ Butler's theory is founded on the deconstruction concept of deferred meaning. As it relates to frames and framing, she suggests that as with the deconstruction of language, each iteration of words moves further from the original intended meaning, therefore, one can never arrive at meaning because it is continuously deferred. Similarly, in each attempt to re-frame, whether it be literally or discursively, is essentially a reiteration and will never achieve what was contained in the original frame. This ultimately is what accounts for the instability of discourses, and is also why discourses can change over time.
} 
Perhaps most importantly, as a liberating space, the dancehall is a site of community and communal interaction that aspires toward a collective well-being. Beth Lesser explains the social and communal significance of the dancehall as follows: "The dance is a place you could get your supper, have a drink, listen to some music and chat with friends, or dance real close with a partner. You could come alone, with your posse...everyone was welcome" (58). And while not necessarily focused on embodied performances within the space of the dance, both Stolzoff and Lesser capture the physical scene of a dancehall in ways that are meaningful in understanding how it becomes a space where one can metaphorically "lose" one's self, and liberate one's self from restricting social frames. Stolzoff describes his experience of the dancehall by stating, "The atmosphere has a tense, unpredictable quality" (200). And Lesser specifies, Once the sun began to set, the selector would start to pick out records from his vast supply and place them on the turntable. The turntable had a light over it so the selector could read the record labels; but other than that it was all darkness...the audience was here to listen...in the darkness people could really relax...Excitement builds as the evening wore on; the deejays loosened up, enough weed and Dragon Stout had been passed around and the crowd was locked in a groove. The main deejays would be expected to keep up the pace until 2 or 3am, perhaps until daybreak or whenever the crowd stopped dancing and went home $(58,63)$.

The experiences described by these authors who are situated as outsiders and witnesses to the dancehall scene serve to establish the expectancy, promise of escape and refuge that the dancehall represents. 
Oftentimes the expressions "buss," "buss weh,", and "vibes" are used to describe the escapist, affective quality of the dancehall. For example, when one says "a dance buss" it signifies an explosively ecstatic eruption that takes place at the height of a "session" or "dance," and might be considered synonymous with how one would experience a sexual climax, a release, an escape. This may happen when the dance is in full swing, or when the selector or deejay is exceeding his best "juggling" of the night, as he deftly chooses in succession rhythms and songs which are communally viscerally meaningful. Similarly, "buss weh" implies a moment of breaking away and metaphorically becoming untethered. In other words, by exceeding the boundaries of a singular self to experience a collective and communal ecstasy, the dancehall affectively undermines the previously restraining frame to become re-framed as a site of refuge for its practitioners. The "vibes" of a dance can be explained in a similar manner. "Vibes" alludes to a feeling of euphoria brought about in the space of dancehall. One can also refer to a person being "full o' vibes," or "vibesy," in the dance, meaning they are lively, bubbly, expressive, exuberant or uncontainable in that designated space.

One popular song that best captures and articulates the affective and communal space of the dancehall is Buju Banton's and Beres Hammond's hit "Pull It Up." In this song, Hammond praises the skills of the "selector" while explaining the community's collective response to the phenomenon of dancehall when he sings:

Yes, you got me rocking in a corner,

With all the lights turn down low.

\footnotetext{
12 The complete expression is "buss weh like a bagey kite." This describes a large kite that has broken away from its tethering and gets swept up and carried away by the wind.
} 
Can't express how mi glad mi come on ya,

I've never seen so much good vibes flow.

Everyone inside is like family, yeah,

I see no strangers around.

The whole massive is here,

And tonight we nuh care.

Kill the violence dead,

Mek we rock it instead.

Jump and palave every man get red now.

(Yes you've got me rocking in a corner

With all the lights turned down low

[I] can't express how glad I am that I came

I've never seen so much good vibes flow.

Everyone inside [here] is like family

I see no strangers around.

Everyone is here

And tonight we don't care

[Stop all] the violence

Let's [dance] instead

[Let's] jump around and enjoy ourselves; every man get intoxicated).

Apart from the basking in the euphoria of the music, Hammond and Banton make several references to the importance of the varied experiences taking place in the communal setting of the dancehall. Their fellow attendees are "like family," because 
within that space where no trespassing is allowed, only insiders are welcome; but what is more, once you are present there, you are no longer a stranger. Additionally, Hammond sings, "the whole massive is here," suggesting that no one who matters has been left out of this experience; everyone who understands what the dancehall can deliver has shown up to partake in this affair. Most notably, to underscore the rhetoric of escape from the drudgery of their everyday lives, Hammond stresses, “....tonight we nuh care/ Kill the violence dead/ mek we rock it instead." In other words, all dire concerns, such as the struggle of daily survival in poverty and crime-ridden communities, have been left at the proverbial/symbolic door of the dance. What takes place inside allows the participants to surpass or exceed, at least momentarily, whatever physical or materially framed boundaries with which they have to contend in their everyday lives, outside the mythos of the dance. Not wanting to return to those confines of the socially and economically imposed restrictive frames, Hammond continually asks the selector to rewind the music. He implores the selector to: "Lif' it up, jack it up, pull it up, come again," (all colloquialisms meaning to "rewind" or "start over") so that he might prolong this moment of escape. Evidenced also by his plaintive refrain "Can you play some more? Can you play some more?" Hammond intimates that he and "the whole massive" are all too aware that once the music stops and the session ends, this temporary reprieve has been just that: temporary.

Butler's theorization of the frame is also suggestive in reading dancehall culture in terms of the physical space of the dance. Because, as Butler argues, framing is inherently insecure and causes a sort of destabilization, dancehall culture is no longer only located or fixed in a segregated hinterland separate from the rest of "decent" 
society. ${ }^{13}$ Rather, because of the newly pushed borders caused by incremental re-framing and re-zoning, dancehall's cultural intervention into the sociocultural landscape of Jamaica is both symbolic and physical, so much so that "it is almost impossible to move through Kingston's urban public spaces without encountering dancehall in some form" (Stolzoff 1). Therefore, because of the pervasiveness of dancehall culture, social and cultural power relations become unhinged, as the penetration and transcendence of real and perceived borders re-locates dancehall as a phenomenon that is simultaneously marginal and central, much to the consternation and anxiety of the social and cultural elites (Niaah 153). In other words, dancehall has now become a "de-centered center," which consequently allows it to manifest itself in a multiplicity of sites and spaces that speaks to its un-"boundedness" (Niaah 153). As a cultural phenomenon it simply cannot be trapped, bounded, affixed by the frame because of the sheer force of dancehall's subversive nature. In response to both dis/place/ment and confinement, or what Paul Gilroy refers to as "the curse of homelessness or enforced exile," the "border clash" between power and marginality yields a space where dancehall culture is able to perform its undoing of unstable frames and borders (qtd. in Niaah 34). Niaah makes a similar conclusion when she explains, "out of such marginal spaces as the ghetto, performance cultures are consistently emerging; challenging the very contexts that militate against their emergence" (153). But further, we find that dancehall as a performance culture is not only coming out, as in unflinchingly emanating from its controlled and policed areas,

\footnotetext{
${ }^{13}$ Thus, again, the "downtown" where dancehall culture originates is not a land-locked place geographically separated from the rest of society; dancehall from "downtown" is a roving cultural form.
} 
but in so doing, its liberatory impulses interrogate the cogency of the socio-cultural border patrol.

I would argue, then, that the charged cultural border deploys such contestory acts not only through lyrical performances, but through embodied ones as well. While lyrical performances are central to the ways in which dancehall defines itself as a culture of resistance, to be sure, critics have also recognized the resistive, subversive, performative physical body as bearing symbolic value in this sense. The symbolic use of the body as a means of publicly performing one's existence in the spaces of dancehall has been viewed as an implicit designation of the body itself as a ritual site of contestation. In Reggae cultural studies, the performances of excess previously alluded to in terms of the ecstatic acts of community performed at "sessions" have been recognized as "spiritual acts of self-affirmation...that bestow[s] cultural and social empowerment" that openly defy and challenge the cultural imperialism of the upper class (Inna Di Dancehall 128). Lowerclass blacks, as degraded and negated subjects within the social structure, adopt ceremonial bodied ritual performances of dancehall, which allow for the possibility of renegotiating potentially transformative identities. Therefore, the "total theatre of dancehall" provides a liberating space where the body is able to act out against its cultural and social exclusion (Cooper 5). The "total theater" is comprised of lyrical, musical and embodied actions which all serve to work against the socio-cultural homogenization and represents yet another kind of clash between power and marginality.

When discussing skin bleaching, if the skin is the organ which defines the limits of the body, it can be plausibly argued that bleaching is one of the embodied actions performed in the theater of the dancehall space. I wish to assert, therefore, that skin 
bleaching should not only be regarded as a fashion statement or form of dress and adornment, as it has typically been read, but it certainly carries unmistakable political implications- political in that as a performance, bleaching fearlessly engages the social body politics that undergird the inequities derived through race and color in a social structure informed by colonial racist/colorist discourse. The discursive binaries that establish and reinforce social differences of "wi vs dem," high and low culture, uptown and downtown, upper and lower class, which are so intricately linked to skin color, are effectively parodied and consequently delegitimized by the bodied queer performance of skin bleaching. Nikki Sullivan establishes the concept of "queer" as one that "continues to struggle against the straightjacketing effects of institutionalization" (v). In much the same way, skin bleaching as a function of queerness, struggles against and works at shifting with a view to dismantling the borders of institutionalized colorism and racism and all the added limitations that ensue therein. The objective of performing skin bleaching, therefore, is not to re-make or re-draw new borders of/for the marginalized body, but to gesture toward, while further widening the confines of said borders. Thus, the signification of the "re" is effectively to not arrive at a new status quo, but to continuously question the efficacy of a social structure that sustains existing rampant inequities rooted in a politic of the body.

Acts of self-presentation that play with the body, and especially parts of the body that are considered to assert social identities (to be socially defining), are often misrepresented as aberrant, or otherwise abnormal. Yet there have been interventions seeking to interrogate these bodies through the engagement of social and cultural contexts. Visual artist Ebony G. Patterson is one such interventionist, who with her art 
explores how socially non-conforming bodies within the dancehall space stage narratives that contest and expose unstable discourses and social institutions. Patterson, who describes her work as "camp," takes a postmodern approach to probing the body politic of gender, beauty and color/race particularly in dancehall street culture. She explains that she draws on Susan Sontag's definition of "camp," that identifies the elements of "artifice, playfulness, exaggeration, kitsch, theatrics," all of which Patterson claims embodies the ethos of dancehall performances ("Fashion").

Like Hope, Patterson's work began with exploring dancehall masculinities in

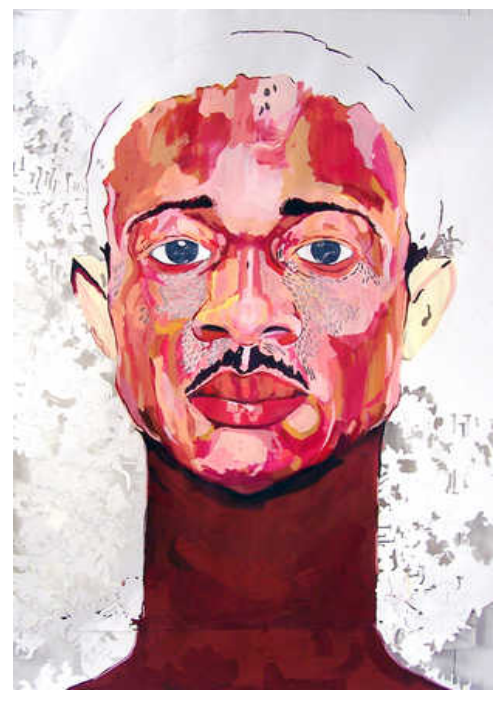

Figure 1: Untitled III, from Gangsta For Life collection, 2007. relation to homosexual stereotypes synonymous with dancehall culture. Works from her exhibits, "Out and Bad," "Gangsta For Life," and most recently "Cheap and Clean," attempt to deconstruct the discursive limits of masculinity within dancehall culture by focusing on fashion and other embodied performances such as skin bleaching (see fig. 1). The "Gangsta" and "Bad" aspects represent, and are informed by, the hyper masculinity that is communicated through the aggressive and macho male subject who is

synonymous with dancehall culture. Ellis further clarifies:

Within dancehall, 'out and bad' implies a certain form of glamour and confidence-the phrase designates someone who is unabashed about his $^{14}$ skills and looks, who enjoys prominence and spectacle, whose confidence is wed to an

\footnotetext{
${ }^{14}$ My emphasis.
} 
investment in being the center of attention. Out and bad is also, felicitously, ${ }^{15}$ a yoking of two discrete discursive fields: US-style queer politics and Jamaican masculine imperatives (9).

Interestingly, by choosing to juxtapose and intersect "out" and "bad," which are two culturally contradictory and oppositional identities, Patterson potentially raises questions about not only the stability of the perceived fixed masculine/feminine binary, but she also manages to question the extent to which seemingly oppositional discourses are discrete or can remain mutually exclusive.

As does Hope, Patterson interrogates conceptions of what constitutes masculine and/or feminine beauty and fashion by locating skin bleaching as a previously largely feminine ritual of beautification and self-improvement. Being "Out and Bad," male figures in dancehall culture have adopted bleaching and other "effeminate" aesthetics, such as shaping their eyebrows, wearing flamboyant clothing, engaging in

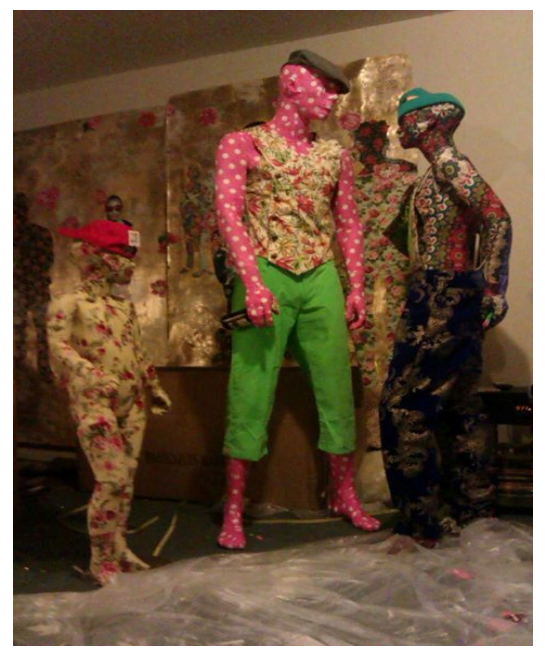

Figure 2: Swag-Swag Krew, from the Out and Bad Collection, 2012.

"erotic, gymnastic and frenzied dance styles," and re-signified them where they are no longer exclusively feminine or masculine behaviors (Man Vibes 134). But further, Patterson deconstructs the bleached body as a site of contestation where "blackness" as a means of cultural affiliation, is no longer signified by the skin. In her exhibits, she presents "dolled" up mannequins that are not immediately gender distinguishable with skin made from colored and patterned fabrics (see fig. 2).

\footnotetext{
${ }^{15}$ My emphasis.
} 
Although Patterson, like Hope, does not label her work as a "queer" critique of gender and color, as that would be itself a discursive limit, she manages to construct dancehall as a physical and symbolic "space to re-negotiate identities" that contradictingly, "re-entrenches stereotypes and prejudice" (hyperallergic.com). The tension between identities being negotiated while simultaneously stereotyped recalls the inability to fix meaning through discursive framing. Patterson effectively exposes the elasticity of discursive limits by showing that bodies in the dancehall space are not immutable and static identities produced wholly in and by discourses projected on to them, but that through interaction with and reaction to the social systems they have the capacity to project their own discourses. In that sense her work is indeed a critique of the queer body politics of gender and color, not only in dancehall culture, but also in the larger social world that dancehall culture contests. 


\section{Part III. Look Pon We: The Communicative Body}

"In demonstrating that race is constituted in a visual field, Fanon exposes the potential for subversion. He demonstrates the possibility of resignification at a visual level..."

Penelope Ingram, The Signifying Body

"In the dancehall dis/place, the body is the ultimate cultural capital."

Donna Hope, Inna di Dancehall

While not intending to perpetuate the perception that in Jamaican society the bleacher as "other" is always a "poor ghetto dweller,"16 the cultural readings of dancehall performances typically focus on the embodied subject who resides on the socio-economic periphery of Jamaican society. This is not to suggest that persons who bleach, or bleached bodies, cannot be located in other social strata, rather it is precisely because they as members of "privileged groups," to use Browne-Glaude's label, are not "othered" by their use of (what could be broadly referred to as) skin-bleaching agents. These privileged bodies have the financial wherewithal to avail themselves of medical expertise, which validate their uses of bleaching agents within an institutionalized framework of acceptability (45). Therefore, the extent to which bleachers or bleached bodies are seen as abnormal or normatively unacceptable must be linked to experiences of socio-economic exclusion. As such, skin bleaching, when performed by bodies belonging to marginalized poorer classes, becomes imbued with meanings which implicate these bodies as deviant, non-conforming, and a result of pathological behavior. Additionally, the normalizing discourses that reinforce dominant modes of interpretation are working to obfuscate the

\footnotetext{
16 Browne-Glaude argues that, in Jamaica, the bleacher is overwhelmingly categorized as a black person from the poorer social classes. This classification, she claims, further reinforces notions that bleachers are deviant, and the practice of bleaching is "evidence of a presumed culture of poverty."
} 
social exclusionary biases that limit socially disenfranchised subjects, while re-producing hegemonic notions of color and class.

Before delving into a conversation on the socio-cultural ramifications of bleaching in Jamaica, it is critical to take a step back and first attempt to anchor, so to speak, the body-an already slippery text ${ }^{17}$ - within a theoretical framework for further analysis. I hope to gauge the extent to which a body receives rather than creates social meaning, and in turn how discourses might be projected on to rather than projected by bodies. Between Michel Foucault's post-structuralist reading of the body as a strictly social phenomenon and Arthur Frank's insistence on the dependence of human action with corporeality, explicit points of intersection and departure regarding how "social forces impinge upon the body" are interrogated (Shilling 62). While these two theories are divergent insofar as the degree of autonomy and agency Foucault and Frank ascribe to the material body, both Foucault's and Frank's contentions conclude that social structure can and does project meaning onto the biological body.

Foucault posits that it is through language that we experience the social world defined by "a whole set of knowledges" disseminated discursively by Power (Power/Knowledge 82). But although Foucault acknowledges that Power does not have the "privilege of consolidating everything under its invincible unity," and as such this vulnerability therefore occasions transferences of Power, he does not explain how that transfer is enacted or embodied (History of Sexuality 16). He emphasizes that owing to the pervasiveness of discourse, the body as an agential, biological entity, ceases to be, or

\footnotetext{
17 Carolyn Cooper uses this term to describe what she sees as the challenges inherent to trying to fix cultural studies as a discipline. I found it equally useful in describing the difficulty with situating the body as a fixed text to be read.
} 
never really is an autonomous biological phenomenon, because it is wholly constituted in, and controlled by, discourse. Thus, Foucault's primary contention is that the materiality of any body is performatively, but more importantly, discursively produced (Shilling 70). In sum, for Foucault, a body has only as much significance or autonomy as the discursive structures of Power affords it.

Institutionalized and dominant discourses then, have the influence to frame specific bodies according to varied social and political agendas, which are never valuefree, as they work in the service of a presumed authority. Consequently, using a Foucauldian rubric, a bleached body in Jamaican society would be classified within a racial discourse as "black," then other discursive associations would render that body: poor, uneducated, ghetto, unruly and abnormal- differences all discursively antithetical to that which is considered "good." Religious discourses, for example, could be used to reinforce that status quo. Discourses of morality and decency firmly rooted in Christian principles of piety and modesty are used to frame dancehall culture (i.e., black performance) as decadent and debauched, and therefore any practices associated with that culture becomes vilified by society at large. As such, we observe layered discourses being used to situate dancehall and its practitioners outside various loci of social acceptability. These same discourses simultaneously detract from real issues of broad structure inequalities that have placed specific persons on the fringe of society.

Chris Shilling, however, points out that one major critique of the Foucauldian construction of the social body, hinges on Foucault's inability to extricate, as it were, the material or corporeal body from its social or cultural structures. This, Shilling argues, results in what he terms "Foucault's vanishing body" (69). What he means is: for 
Foucault, the materiality or corporeality of the body is subordinated, and indeed ordered, by the social world that exists outside it. Thus, although Foucault acknowledges that the body is "infinitely malleable and highly unstable," his disembodied reading of the body seems to preclude the body's ability to act out challenge or resistance insofar as it is constructed discursively (qtd. in Shilling 67). Therefore, Foucault seems to postulate that even if the social construction of body is malleable and unstable, such fluidity is only relative to the instability of the power of discourse. However, we must consider how discourse works on the body through lenses of correlation or causality. That is to ask: does the body's capacity to resist only correlate to the instability of discourse, or can the actions of the body cause the instability of discourse? And further, what can a material body do to "speak out" against and destabilize dominant discourses? Or, how do counter discourses emerge if not for actively resisting and reactionary fleshy bodies?

Frank's view may provide answers to my questions specifically because he envisions a social body with decidedly more agency, and one which constitutes rather than is constituted by "discourses and institutions" (qtd. in Shilling 83). By identifying the body as a corporeal phenomenon, Frank figures four ways that the material body is linked to social action, and explains how it experiences social systems. Shilling summarizes as follows:

For the disciplined body the medium is regimentation, the model of which is regimentation of the monastic order. For the mirroring body the medium is consumption, the model of which is the department store. For the dominating body the medium is force, the model of which is war; and for the communicative 
body the medium is recognition, the model of which could be shared narrative, communal rites and caring relationships (84). ${ }^{18}$

Frank's theory of the socially constructed body initially appears overwhelmingly structuralist and synchronic (structurally synchronic?), as he presents fixed ideals and "types" that seems immune to temporality and social influences. For example, across cultures and societies regimentation will not look or mean the same, so can his conceptualization of the "disciplined body" remain stable across place, space and time? Can one body navigate between these different types Frank identifies? And if so, what would prompt these moves or changes? Quite the inverse of Foucault, Frank seems to have taken social systems so far away from the body that he too offers little explanation of how the material body would respond to or effect change on existing social institutions. His "communicative body" theory, however, provides the most provocative and useful insights into how the body interacts with society, and vice versa. Shilling goes on to describe this "type" as "less reality than future possibility" (85). In this communicative body, the "future possibility" may help us re-imagine the material body as a potentially potent social symbol. If, as Frank claims, the communicative body has "the capacity for recognition...through the sharing of narratives which are fully embodied," then the body's potential to speak, and therefore argue, provides an essential component of a dialectic configuration between the body and society (Shilling 86). Frank's communicative body may well be Foucault's vanishing body made visibly audible; indeed, a communicative body, and therefore transactional body, might be constituted as a receptor of, responder to, and supervening generator of social meanings.

\footnotetext{
${ }^{18}$ My emphasis.
} 
Therefore, as a reactive subject, the communicative body as a highly malleable corporeal body can effectively be used to project discourses or counter discourses through the staging of embodied actions that engender resistance.

The fluidity and malleability of the body when read as a text of narratives precludes it from being confined by any particular "work", ${ }^{19}$ as Roland Barthes might claim, and similarly the material body is not able to be reduced, framed or represented by any one set of knowledges or discourses that aspire toward definitive meaning. If we conceive the body as a text, it is therefore inscribed in and by a language, or by a system of signs. Specific to the discussion on skin bleaching, as an extension of the physical body, and some would argue not merely an extension, but marking the limits of the body, the skin has a particular semiotic capability. Described as the "visual grammar of the body," in the "scopic economy" of racialized discourses, skin as a social idiom extends beyond being a physical descriptor. Much like the science of semiotics, on the skin allows us to "access... whole historical and social processes that expose not only the truth or falsity of single statements, but the logic and culture of whole realities" (260).

\footnotetext{
${ }^{19}$ The seeming disjuncture between Foucault's and Frank's conceptualization of the social body are potentially reconciled by Roland Barthes's breakdown of "the work" and "the Text." Though Barthes's essay focuses on an experience of the literary, the distinctions he makes between "the work" and "the Text" can theoretically substitute for society and the body in an analysis of the relationship between the two. If we assume the malleable and unstable body to be Barthes's "Text," then Power- consisting of the social "real" founded on traditional institutionalized "knowledges," "old classifications," and "shared conventions of meaning-making" can represent his conceptualization of "work." In this case, through the sharing of narratives, Frank's communicative body can indeed be appropriated as a model for "the Text." "To share" in this context articulates both Frank's and Foucault's position in that it alludes not only to share as in "a distribution of," but can be taken to mean the narrative inscribed in and by "the Text" is "comprised", or "made up of" shared experiences which constitute "the Text." The body as a text then, is a sum, and not summation of all the experiences inscribed thereon. The multiplicity of experiences as inscriptions are possible as "the Text," Barthes claims, "can cut across work, several works." Finally, the body as a concept, it could be said, is made up of interactions with and by numerous discourses or works.
} 
Engaging Barthes, Mansfield surmises that, "the text becomes undone where the seam between meaning and meaninglessness comes most under pressure," and I would submit in addition to becoming undone, the text has the capacity to be re-done at Mansfield's seam as well (264). Accordingly, the body as text can re-shape and re-form itself where socially constructed truths, such as race, are at their most precarious.

Therefore, while Foucault is correct that the power of discourse constructs bodies, and in this discussion we have identified the power of discourse to construct racial bodies, we still find that bodies are not limited entities, as they can be a "subversive force" that through signification disentangles "the work's" "network of conditioned meaning" ("From Work" 1327) Foucault rightly claims that Power is always in flux and therefore can shift a movable center, from one discourse to the next, but the question remains: how does this shift in occur? Barthes argues that with the text readers or consumers are "the site of radical disjunction between conditioned meaning and its disruption" (“From Work" 1328). Therefore, I would venture that if we read the body as a text, performers, who control said bodies, are that "site of radical disjunction."

In much the same way that the reader "plays" with the text as a negation of determinate meaning, the dancehall performer "plays" with the body, the bleacher with the skin, toward the same end. In dancehall culture, the space of the dancehall provides a site wherein the black lower-class, through their actions, can use their bodies to dispute dominant social meanings already projected on to them. Hope explains, "[t]he dancehall as an inner-city and lower-working-class culture encodes [the] fear of poverty and deprivation and negates its play across the bodies of its adherents..." (41). Like Barthes's act of play, Hope sees play as a means by which cultural production is specifically in 
response to and resistance against "the work" and it's "conditioned network of meanings." It would seem therefore, that responses to discourses or the emergence of counter discourses are dependent on the body engaging in "play, activity, production [and] practice" ("From Work" 1330).

So finally, does the body's capacity to resist only correlate to the instability of discourse, or can actions of the body cause the instability of discourse? I believe what I have attempted to show here is that the body and its relationship to society is not reducible conclusively to an either/or binary or dichotomy. Embodied action is the result of a ceaseless interaction between the social body and the biological body that yields what might be thought of as a type of cyclical genesis. That is to say, encounters between the body and its social environment, particularly as it relates cultural production, renews into different expressive forms that will always run counter to existing discourses and institutions. The nature of embodiment, Howson writes, "places emphasis on the interaction between social and biological processes. The concept of embodiment alerts us to the relation between the objective, exterior and institutionalized body and the sensual, subjective, animated body" (14-15). As such, embodied cultural interventions stage events and ruptures that continuously start, change and re-start, as opposed to start, coming to completion and then stopping. The various emphases on inter/ference, inter/action, inter/section between the body and society is reminiscent of my earlier theorization of the signifying "re." The "inter" that links the body and society through embodied action not only signifies a reciprocal transfer, but also a body being in the midst of, a body engaged in an elliptical movement, a body that dances around a final signifier, and is an embodiment of "queer" performance. 
It is in terms of the possibilities inherent to the communicative body and its dialectical relation to society that I employ the term "queer" as a nominative useful to construct and think through the bodied bleached dancehall performer. Using the work "queer" to critique dancehall performance and performativity is in many ways problematic, particularly because dancehall culture is one that is notoriously homophobic, and the word "queer" at one time signified non-normative sexuality that was decisively non-heterosexual. In our historic moment, "queer" might take on an emphatically different signification in the domain of cultural criticism, and is therefore no longer limited solely to discourses on gender and sexual identities. Butler too observes that "queer" now operates meta-discursively, in that the word itself has been "queered," at least critically. In other words, "queer" no longer refers exclusively to the deviant from the deviant/normative binary. As such, the word no longer has a fixed semiotic- or is it linguistic?- identity, because it has been appropriated by official critical discourses and now certainly deviates from the "deviant," since it has turned into a normative way to argue non-normativity, sexual or otherwise. In a contemporary culturally critical context, to invoke the term "queer" however is to tend more toward the interrogation of normativity, or the displacement of official knowledge or meaning as dictated by dominant discourses, including but not solely limited to those focused around sexuality. At the same time, I am fully cognizant of and deploy purposely the richly suggestive historical, political and cultural layers that underpin my invocation of the term here to undo and unmake.

Accordingly, I situate skin bleaching in dancehall within a queer paradigm as being a modified body that seeks to disrupt or discursively unfix binary categories on 
which the colorist Jamaican society is built. I wish to make clear however, that my assertion is not that skin bleaching is necessarily a "willful act of self-narration" that tries to be intentionally subversive (Pitts 46). While some dancehall performances are obviously more willfully subversive, and here I am thinking about lyrical and dance performances, others might be less so. Still, all these performances taken together can be categorized as signifying practices arising from a subversive culture that is known for various embodied performances which seek to re-fashion and re-construct selves in contestation of dominating normative ideals. Hence, for the purposes my thesis, the bleacher, the bleached body, and bleached body as subject will serve as a discursive possibility and a theoretical "site of significant social contest" (Pitts 17). As a discursive and semiotic possibility, Victoria Pitts locates the body as a product of postmodern culture, and asserts that, "In postmodern culture, the breakdown of modern power's traditional authority over the body and identity appears to render possible new symbols, meanings and options for the body" (30). To that I would add that new meanings and options are available for the body in the subject's quest to re-construct identities, to delimit imposed identities in order to radically displace traditional authority and knowledge.

Traditionally authorized ways of knowing, coded in medical and scientific discourses ${ }^{20}$ for example have tended to examine occurrences of skin bleaching among

\footnotetext{
${ }^{20}$ Barthes makes the argument that science is used by social institutions to determine what counts as knowledge. "Science," he claims, is the name given by society to what it is conventionally agreed constitutes knowledge. As Science is also constituted in language, he concludes that it is also a discourse and cannot avoid the problematics associated with language and discourse, insofar as language is subjective cannot arrive at a finite meaning. Science then is only a particular way of saying things disguised as irrefutable "knowledge."
} 
Jamaica's black lower-class populations as a purely biological phenomenon rather than a social one. In failing to engage possible social, political or cultural antecedents, medical and scientific interventions have resulted in what Hunter identifies as missed opportunities. Hunter submits that a fear of engaging complex social, economic, and political discussions with regard to the practice of skin bleaching has led to the emergence of a superficial and insincere debate coded in medical and scientific discourse. Subsequently, as Hope points out, medical interventions have proven less than effective in unearthing root causes of, or alleviating the practice, as bleachers are not at all oblivious to the biological consequences of prolonged use of bleaching agents on their bodies, yet they persist.

Indeed, in my conversations with a group of people from the Burgher Gully ${ }^{21}$ area of Kingston, all of who identified themselves as either past, present or occasional bleachers, the threat of physical harm in no way dissuaded those who bleached from continuing to do so. When asked why they did or continue to bleach even while knowing the full effects of applying these harmful chemicals to their bodies, the respondents commented flatly that they just did not care, that they have never seen damage happen to someone they know, or that they did not "go hard" with the bleaching, meaning that they somehow tempered the practice in order to lessen the chances of bodily harm. Some explained that they diluted chemicals or bought milder treatments to achieve this less harmful effect. Curiously, distinctions were also emphatically made between bleaching

\footnotetext{
${ }^{21}$ Burgher Gully is an area of the Mountain View Avenue community in Eastern Kingston, Jamaica. It is identified by a resident, Orlando Patterson, as one of eight "garrison" communities in the urban Kingston area. A term coined by the late Carl Stone, prominent Jamaican political scientist, a "garrison" is a community usually marked by strong political party affiliation, homogenous party voting, high levels of crime and unemployment, and unstable social infrastructures.
} 
and "toning," as "toning" presumably is considered the lesser social infraction. As one woman took care to point out: "I don't bleach, I tone." Her differentiation was made quite possibly as a consequence of the negative and pejorative discursive associations made by being identified as a bleacher, and may also imply that any medical interventions would not relate to those who "tone" rather than bleach. Furthermore, the group did not register care or concern as a rationale behind institutionally-backed, medically-motivated, antibleaching campaigns, as they were well aware that many bleaching products are available only as a result of legitimate, state-regulated importation channels, which are quite outside of their own reaches of power and influence. In their minds, the same "big man"22 who imports and profits from the sale of these products proved less than credible in making gestures to influence the cessation of their usage.

By framing the social practice of skin bleaching in only scientific and biological terms, in effect what medical discourses have succeeded in doing, as Browne-Glaude claims, is pathologizing skin bleachers as not only biologically defective, mutilated bodies, but mentally defective for knowingly harming themselves without care of the consequences. Indeed, Pitts notes that acts of body modification have been construed by "therapists, psychiatrists...as an emerging social problem, ${ }^{23}$ calling them instances of self mutilation" (11). Arguably, use of the word "problem" to delineate these social practices illuminates that there is no effort to understand the "how" or "why" of the production and circulation of these social practices, more than the need to "fix" these physically nonconforming, biological bodies; and too, there is a thinly veiled implication that these

\footnotetext{
${ }^{22}$ Term used colloquially to allude to men of financial means and sociopolitical power.

${ }^{23}$ My emphasis.
} 
bodies are mentally non-conforming as well. Hope and Browne-Glaude both make reference to the large scale "Don't Kill the Skin" campaign undertaken by Jamaica's Ministry of Health. The campaign, they explain, was aimed at aggressively targeting, with the intent to eradicate, the sale and subsequent use of the highly toxic products that were used for skin bleaching. Interestingly, the policing and regulating poor black bodies was accompanied by pro-"black" rhetoric that sought to promote "black" self-awareness and pride (Browne-Glaude 34-35). The latter approach, as suggested earlier, presupposes that instances of bleaching are borne out of either the lack of a healthy sense of self, or a racial identity crisis, both of which need to be "righted." Either way, when framed as a manifestation of an unhealthy mind and resultant unhealthy body, the bleached body ceases to be one that can be decoded within a socio-historical context of "race" and color, whereby race underpins inequitable social structures that might influence skin bleaching. Instead, as a biological (not social) entity, the bleached body becomes oversimplified as an individually wrought problem or defect that is viewed simultaneously with "repugnance and fascination;" repugnance as the defective, physically mutilated body symbolizes an abjected "other," and fascination because as an "other," the bleached body becomes an object of curious, fascinated and condemning gazes (Pitts 11).

The discourses projected on, and subsequent gazes drawn by, the bleached body reveal how medical interventions are yet another way that marginal dancehall identities are attempted to be socially limited, foreclosed and controlled. Institutionally, these discourses erect a sort of "smoking mirror" that implicitly reinforces "blackness" as a biological fact, as opposed to a social construct. This occurs, as Browne-Glaude contends, because "when the body is transformed or modified, [the] concept of blackness 
is destabilized and efforts are made to re-center it" (47). Effectively, the capacity to bleach away one's pigment signals yet another crisis point wherein the configuration of the traditional social color hierarchy is threatened, and there is a consequent anxious rush at re-framing and regulating that interruptive and non-conforming body. Instead of reading these bodies as performing social resistance, pathologizing bleaching as a medical or mental defect detracts from addressing structural problems of inequality and exclusion which are themselves grounded on race and skin color, and shifts focus to the individual body outside of its social context. By this I mean the body is no longer seen as produced by, responding to, or engaging with the social world, but is simply a biological phenomenon functioning, or rather mal-functioning, quite independent of social influences. Thus, through the lenses of medical and scientific public discourses, the bleached body reinforces the very limits it attempts to displace. That is to say, the bleached black body as one that does not adhere to laws of nature is reified as "other:" abnormal, in need of control and regulation, eliciting what Pitts calls "increased surveillance" (46). As such, the biologically non-normative body is ogled and produced as a social object that is now impotently voiceless.

Yet, the gaze is particularly seductive for the bleacher, since in effect one has to be looked at in order to be seen, and indeed, apprehended. Many dancehall performancesbleaching among them- are done with the explicit intention of being seen and admired. The bleachers I spoke with expressed a desire for heightened visibility as one motivation for bleaching. They explained that, not only in the physical space of dancehall, but in their communities of friends or peers, they wanted to be seen and noticed and seen as belonging with a particular group. In the physical dancehall space, costuming enhances 
the performance of alter-ego identities. Among the group, two men who identified themselves as dancers explained that their appearance was integral to garnering accolades and attention when they "featured," or presented themselves at, a specific dance. Outside the dancehall space, the bleachers still wanted to be identified, using the same costuming but in a different way, as being part of collective. There was a decisive rhetoric of visibility used when the group described what benefits they perceived in bleaching. When explaining the transformative aspects of bleaching, the group used words such as being made "brighter," "clearer," or "shown up" by their modified skin tone. Though some implied that they bleached for their own sense of pride in their looks, and not for how others might respond to them, others confessed that the attention they received was addictive and influenced them even more. But as though to confirm Pitts's conclusion, along with heightened visibility some bleachers expressed discomfort at becoming or being overexposed. Again, as with the differentiation insisted upon between bleaching and toning, the speculation here is because of the negative public discourses condemning the practice of bleaching, these persons felt subjected to increased surveillance. It must be noted however, that this scrutiny did not foster a sense of disempowerment, as the group conceded bleaching was only one way among many that they could transform or re-make themselves in order to be seen.

One typical mainstream journalistic effort that does seem to disempower, objectify and expose the bleached body in complicity with traditional institutionalized discourses, as well as reify the bleacher as "other," is the "The Skin Bleaching Phenomenon" documentary produced by Television Jamaica. As part of the "All Angles" documentary series, investigative journalist Dionne Jackson Miller, prefaces the film as 
seeking "to document what is happening and why" with regard to the phenomenon of skin bleaching in Jamaica (All Angles). The documentary is rife with inconsistencies by putting forth a narrative that claims to be interested in why this sociocultural practice originated and persists, yet glaringly shies away from historicizing factors such as racism, colorism or other colonial discourses that have shaped an unequal Jamaican society. Apart from some strategically placed sound bites from cultural studies professor Dr. Donna Hope, as a purported social investigation the documentary film is both a representation and representative of how specific bodies are made discursively to vanish.

The majority of the documentary shows Jackson Miller in the "downtown" urban area of Kingston interviewing various women and one man, who bleach. Responding to the question of why they bleach, similar to the responses I garnered, some women indicated that they either "liked" the lighter, browner skin color as it made them "more prettier," or that they thought their skin was too dark as is, and bleaching "bring [them] up likkle more" (Brings them up a little more). Still, some responded that because of their professions as beauticians, a lighter skin tone made them more visible to potential customers- visible in the sense that a lighter complexion was deemed more attractive as it implied some degree of sophistication and modernity, and moreover because "when yuh black nuh baddy nuh si yuh" (When you are black nobody sees you). Some interviewees also identified skin bleaching as "fashion ova style" ${ }^{24}$ - a fashion statement that gives one a more "glammy look"- a glamorous look. These responses all reflect sentiments no doubt at least underwritten by ubiquitous mass media representations of female black

24 "Fashion ova' style," which translates to "Fashion over style," is a colloquialism that speaks to one keeping up with current trends from the margins as opposed to being confined by dominant and centralized concepts of what it means to be stylish. 
popular culture icons like Beyonce, Rihanna and Halle Berry, but arguably also by the fact that in Jamaican society oftentimes skin color is a referent for social class and mobility. While she discusses broader social issues and causes, albeit quite briefly with Dr. Hope's intervention, Jackson Miller noticeably does not engage her subjects on matters of social mobility, accessibility, or how and why they feel these constructions of beauty and glamour have ascended.

Jackson Miller endeavors a thorough analysis of "what is happening and why," by engaging her subjects with questions obviously geared toward gauging some degree of identifying a psychic process that may explain the social practice. Additionally, she solicits academic as well as medical insight from Dr. Hope, and dermatologist Dr. Neil Persadsingh, respectively. Where Jackson Miller's approach becomes problematic however, is when she decides to shift focus from engaging her subjects in sociocultural dialogue, and begins to focus on the chemical concoctions mixed and used by some to bleach; or to put it another way, Jackson Miller begins to focus on her subjects as biological as opposed social beings/bodies. One woman in particular, identified as "Bobbet" is featured extensively. Bobbet is shown mixing bleaching agents into a bottle and then rubbing the mixture of creams and gels onto an unnamed woman whose face is blurred out. This anonymity might have been to preserve her privacy, but effectively this woman has been made into a faceless, nameless prop, a biological specimen, an object used for demonstration purposes only. Occasionally, Bobbet interjects commentary to explain her mixing and application process, and it becomes apparent that she is in front of an audience who is behind the lens of the cameras, as her comments are met with chuckles and laughter. Within the frame of the camera, Bobbet and her companion are 
objects on display, whether willingly or unwillingly; they are now spectacles under scrutiny because of their "abnormal" bodies. Within the frame of a broader social context, certainly unwillingly, they are circumscribed by discourses that have all too easily dispensed with their identities, and re-inscribed them as "other."

Additionally, in segments of the documentary, Jackson Miller shifts back and forth between stories being told by her various subjects of bottled concoctions exploding in refrigerators because of their toxic and volatile contents; cautionary tales of fungus developing on the skin if creams are not administered correctly; skin "bussing" (bursting or separating) into open, weeping wounds caused by prolonged use of bleaching agents that have worn away the epidermis; and women confessing to not bathing for days in order to "reach" and "come quick" (in order to arrive at their desired skin tone at a faster rate) in preparation for a "dance." At these points in the documentary, one has to wonder how or why such details are fundamentally salient to an exploration of "how and why" skin bleaching is "happening" within a designated community. The initial assumption, given Jackson Miller's own preface, is that the "how and why" would be a sociocultural inquiry into the production and circulation of bleaching as a cultural practice. There seems to be an element of sensationalism attending this type of investigative work that promotes condemnatory voyeurism and inflexibly situates the subject of investigation as an object. As a consequence, despite Jackson Miller's efforts to have these women and man represent themselves, the degree to which she obstructs their voices by her discursive framing dis/places them as true interlocutors. By stressing the toxicity of the creams and the potential harmful effects of their usage, Jackson Miller succeeds in eliciting from the audience reactions of "repugnance and fascination" at the prospect that 
people can and do harm themselves in this way, simply for "fashion." The implication of bad hygiene also serves to further propel the widely perpetuated notion that people who do "this sort of thing" are certainly deficient in some way; they are poor and therefore uneducated, ignorant, mentally enslaved or possibly mentally unsound.

It is no wonder that when it comes to the power of visual representations to shape the self and subsequent identity, Peggy Phelan is concerned about the degree to which the "spectator dominates and controls the exchange" (qtd. in Pitts 46). To be sure, one only has to read the YouTube comments attached to the video of the documentary to witness how spectators have re-framed the documentary's subjects through various marginalizing institutionalized discursive lenses. It is even more troubling since as an often underrepresented and misrepresented group, the man and women interviewed have only been afforded limited to no opportunity to equally engage in discussions about themselves and their lived experiences. It is not my intention to suggest that Jackson Miller's was not a thoughtful or thought-provoking project; she did indeed explore all angles; only some more than others. However, her approach is exemplary of how social meaning and discourses can be projected onto, rather than be projected by bodies and end up being a truly missed opportunity for productive social engagement.

In one conspicuous opportunity missed, Jackson Miller asked the bleachers how they reconciled bleaching as not being contradictory to black identity and pride. A respondent identified as "Monica" asserted firmly, "No, ef yuh even interview somebody else dem nah go tell yuh a true dem nuh like black, trus' mi" (No, even if you interview somebody else they won't tell you [they bleach] because they don't like [being] black, trust me), meaning that at least her decision to bleach was not attributable to a negative 
self-image of her blackness or African ancestry. The same question occurred to me in my conversation with bleachers. Like Monica, they commented explicitly that for them the decision to bleach had nothing to do with being "too black." During our discussion, after one moment of introspection a man stated while pointing to his skin, "The black is not this." This pronouncement suggests to me that this man's perception of what constitutes "blackness" far exceeds the skin he is in. His self- identification as "black" is more rooted in cultural practices and affiliations as opposed to simply physical appearance. However, when I asked for further clarification he went on to explain that even if he bleached himself to a lighter skin tone, if he fathered a child it would still be black. So his "blackness" in this sense was inescapable, as he is genetically encoded to be "black," and bleaching is incapable of eroding that biological design; either way, who he is is not defined by how he looks. Others in the group as well, contrary to the widely held belief that bleachers somehow have "lost" connection with their "true" selves, agreed that they were well aware that bleaching did not change who they were, and their purpose in bleaching was not to become "brown" or "white," but instead to exert an individual authority over their own bodies in being able to transform themselves at will. ${ }^{25} \mathrm{I}$ found that their constructions of "blackness" traverse a far more complicated discursive terrain than expected, one that cannot simply be reduced to loving or hating being "black." It was curious to note that they all made scolding remarks about other bleachers known to them who they feel "overdo it," go "all out" and hence give bleaching a "bad name."

\footnotetext{
${ }^{25}$ Hope notes with respect to the culture of bleaching, in response to detractors, bleachers readily point out that their skin is their personal property to do with as they please.
} 
Those they claimed were the persons responsible for casting the practice in a negative light as far as public perception.

Jackson Miller's framing resembles other projects- documentaries, articles, interviews- on skin bleaching that I have witnessed, and made me question to what extent specific discursive lenses are deliberate, and if can they be actively suppressed in doing this type of research. Therefore, my primary goal with initiating conversations with the bleachers was to try and deduce what they were trying to say with their bodies, and also to have them assume positions as vocal and discursive subjects rather than impotent objects under scrutiny. It became clear to me however, that conversations on the effects of the physical body were almost unavoidable, as details of application and frequency of application to reach a desired skin shade were often brought up by the bleachers themselves without my prodding. But what I also found was that if we spoke long enough, we would eventually move past the superficial, move past the skin, and toward a more contoured conversation that gave bleachers the opportunity to re-inscribe themselves as autonomous subjects. Although the bleachers did not specifically identify their actions with a named queer paradigm, they do realize their power to manipulate and re-fashion their bodies in ways that trouble and brush up against traditional social meanings that have been projected onto them.

Skin bleaching for many, I came to find out, is seen as an aesthetic enhancement, and not necessarily through the lightening of one's pigment. Claims made by the men and women alike were that bleaching or using bleaching agents was a useful way to alleviate acne, maintain an even and flawless skin, and a part of a cleansing regimen that resulted in "brighter" and "clearer" skin. But beyond these perceived cosmetic benefits, most 
persons valued the capacity to change themselves. One woman conceded that it was "jus' a hype t'ing" (just a hype thing), and that being able to change one's looks was seen by peers and especially in the dancehall culture as not just fashionable, but fashion forward. Another woman claimed that she does it for a "new look" similar to how she would change her weaves or hairstyles, and one man confessed that this lighter skin was his "summer look" for summer dances coming up. When asked by his peers jokingly what his "winter look" might be, he admitted he might get a change his hair or eye color. The man's comment was particularly revelatory as it suggested that he viewed being able to change his skin color as a mere fashion accessory that can be easily substituted by another accessory at his whim. It should be noted that the group explained that once they stopped applying bleaching creams one could and would "get back black," and therefore it is understandable why they consider bleaching as something transient, an element of style that they could stop if they wanted to, depending on seasonal or cultural shifts.

Dancehall performances that challenge status quos are only considered a problem when they are not localized in the space of the dancehall. In other words, if these performances are confined within their spaces of origin, they can easily be, and readily are, dismissed as symptomatic of belonging to or being from those spaces. Being identified as a bleacher, as it was explained to me, places one at an even greater disadvantage than being "black," for example, when trying to seek employment. Public rejection of the bleacher happens because in "circumstances and situations in which gap or discrepancy develops between virtual and actual social identity... have the potential to stigmatize the individual" (Howson 23). As the bleacher is not able to fit into a designated color category, and has effectively compromised his or her assigned social 
identity constructed around race/color, they are consequently treated as social misfits. Further, when engaging with the wider society, it could be argued that the disorienting effect at witnessing bleached skin occurs because "race and racism are discursive regimes predicated on scopic economy" that "regulates meaning through the visual" (Ingram xiixiii). By presenting themselves, or rather by being able to present themselves, contrary to normative expectations, the bleacher is considered to be not only a deceptive body, but a disruptive one as well, and accordingly interrupts the "predictability and stability [expected] in social encounters" (Howson 22). One man commented that when applying for a job, if the decision is between a qualified dark skinned person and a lesser qualified light skinned person, in his experience the lighter skinned person is typically selected. Another man added that "if brown get first choice, and black one get second, the bleacher get third." When asked why they felt this was so, a woman responded: "Nobody won't employ you with 'that,"” meaning with bleached skin. In agreement, another man explained "Nobody nuh waan people inna dem company wid a low esteem" (Nobody wants people [working] in their company with low [self] esteem). In a strange way having bleached skin not only annunciates one's "blackness," because the misconception is that only black people bleach, but also enunciates what being "black" may mean in a society ordered by a color hierarchy, which constitutes blackness as poor, unattractive, uneducated, lower- class and low-brow. The man went to explain that in interacting with persons outside his sociocultural parameters, when it is detected that one is a bleacher, "it wi more mek dem draw weh from you cau' de look a it" (It will more make them draw away from you because [of] the look of it). 
The physical recoil described is also symbolic of a social distancing that can be interpreted as a retreat behind the safety of social barriers that designates the "wi vs dem." Because they have transgressed the borders of their social space and the limits of the social body, to encounter the bleacher occasions "a sense of crisis," that is responded to, as argued earlier, by ardent policing that tries to shore up social borders by redefining what behaviors are and are not acceptable (Thomas 11). This embodied transgression, however, does more than signal a destabilization of traditional values. Julian Wolfreys defines transgression as "acting in some manner proscribed by the various forms of institutions of Law in societies. To cross a line, to step across some boundary and move beyond convention-this is what it means to transgress (3). Critically expanding Wolfrey's concept of transgression however, Chris Jenks adds, "but to transgress is more than this. Transgression is a deeply reflexive act of denial and affirmation" (2). In other words, to transgress delimits borders and more importantly, simultaneously draws attention to the very limits of the confinement. Transgression stresses or emphasizes what it is that is trying to be steadfastly held in place; transgression not only crosses the line, but it shows up the line being crossed, and the unreliability of that line to hold order in place. It is my contention then, that skin bleaching is transgressive reflexivity; by being able to insinuate a color, previously thought of as an immutable fact of biology, the bleached body insinuates itself between, while drawing attention to, the proverbial cracks in the social structure founded on colorism.

Specifically, this act of subversion compels us to confront the efficacy of socially constructed notions such as race and color. As a marginal form of cultural expression 
then, what bleaching affirms is the insubstantiality of colorist discourses that have been used to define and marginalize Jamaica's poor, black lower-class. As Thomas maintains, "Looking at the way power is expressed through the idiom of culture at various institutional levels shows us where the reproduction of hegemonic ideology is at its most tenuous, and therefore where the ability of the ideologies to constitute particular subjectivities is most fragile" (8). In other words, if a "naturally" black person is able to self-present in a way that undermines the natural, presupposes that regimes of truths that colorism as a social designator is contingent on is fallible. Further, it calls into question any successive institutions that have relied upon the validity of these tenets, and ultimately reveals them to be contestable. This is not to suggest that a singular form of cultural expression will cause all previous marginalizing discourses can be toppled; that is almost impossible. Yet considering their totalizing nature, and the pervasiveness with which discourses are circulated, the idea that they can be chipped away at is the felicitous "unfulfilled promise" and the "future possibility" of the queer that Ellis alludes to. Bleaching then can be interpreted as creating incremental shifts which are part of a larger network of queer performances working to push against social frames and thereby creating newly designated sites of clash.

The bleachers I interviewed- and I would venture other persons like them- are not oblivious to the fact that manipulating their skin color will not immediately give them access to a different social circle, long term access to social mobility, or gain them immediate social acceptance. Rather, like other dancehall cultural performances, bleaching has emerged as an "[imperative] produced by powerful norms," which is as much about claiming symbolic power, exercising control over individual bodies and the 
"narration of experiences" as it is about using bodies to perform resistance (Pitts 47). When speaking with cultural studies professor, Dr. Donna Hope, I asked if she saw an "end" to the practice of bleaching, at least in Jamaican society. She responded that to speculate on an end presupposes that this practice is foremost a problem, and that the people who perform this practice need to be fixed, or regulated in some way. Instead she suggested that providing marginalized classes with alternate means of social empowerment and achieving social visibility should be the favored route when contemplating how idioms of culture work. Similarly Browne-Glaude reasons that "the rise of skin bleaching correlates with a confluence of events...that needs serious interrogation," among which she cites "broader social and economic realities [that need to be] aggressively addressed" (51). Therefore, bleaching as an embodied performance within the spaces of dancehall can be interpreted as a response to and interrogation of social and structural impediments that the poor working class black are forced to contend with. In postcolonial societies, like Jamaica, where the prioritization of race and color are deeply entrenched, institutionalized ideologies, the semiotics of skin operate in a much more complex way than trying to determine what being "black" or not "black" is or means as a given and conclusively defined value. Instead, the skin is a part of the system of signs that allows us to read a particular society.

The rhetoric used when talking about bleaching oftentimes alludes to a sense of arrival or pursuit. The expression "bleaching to reach," or "you bleach and it reach," or to say one's color "come" or "coming" is another way to say the practice of bleaching has been successful in that one has attained the desired skin tone. However, bleaching or "bleaching to reach" as signification expresses a search for connection as in "to 
communicate with." In this instance a disenfranchised and alienated class manages to communicate with their bodies to society at large disaffection at their social. Additionally, the infinitive "to" stresses the non-arrival of that reach and much like the signifying "re" symbolizes the reflexive politics of signification, which subversively affirms as it denies the limits of race and color. As with other dancehall styles, fashions and practices that have emerged from this culture invested in "continuous re-scripting the norms of personhood and identity" that serve as a provocation to said social norms, after bleaching there will emerge from this community other ways to signify social disaffection and exclusion (Man Vibes 145).

Therefore, as we witness this new and modern type of blackness that dislocates and transposes previously held historical racial values, it is important that we ask "What are these bodies trying to communicate?," instead of relying on old structures of interpretation. When I asked the group of bleachers what they made of the fact that the discussions surrounding skin bleaching had recently become noticeably amplified with decidedly negative overtones, one woman replied dismissively, "Dem nuh really have nut'n good fi seh 'bout ghetto people" (They don't really have nothing good to say about ghetto people). Perhaps then, it is time we take a step back, see, and listen more keenly to what these marginalized body-subjects are invested in saying for and about themselves. Until then, their pursuit continues. 


\section{Bibliography}

Ahmed, Sara. Queer Phenomenology: Orientations, Objects, Others. Durham: Duke UP, 2006. Print.

Banton, Buju, and Beres Hammond. "Pull It Up.” Unchained Spirit. Anti Label. 2000. CD.

Barthes, Roland. "From Work to Text." The Norton Anthology of Theory and Criticism. New York: Norton, 2010. 1326-1331. Print.

Bhattacharyya, Gargi. "Flesh and Skin: Materialism is doomed to fail." Contested Bodies. Eds. Ruth Holliday and John Hassard. London: Routledge, 2001. 36-47. Print.

Browne-Glaude, Winnifred. "The Fact of Blackness: The Bleached Body in Contemporary Jamaica.” Small Axe 11.3 (2007): 34-51. Print.

Butler, Judith. Bodies That Matter: On the Discursive Limits of "sex". New York: Routledge, 1993. Print.

---. "From Gender Trouble." The Norton Anthology of Theory and Criticism. New York: Norton, 2010. 2540-2553. Print.

---. Gender Trouble: Feminism and the Subversion of Identity. New York: Routledge, 1999. Print.

---. "Precarious Life, Grievable Life." Introduction. Frames of War: When Is Life Grievable? London: Verso, 2009. 1-33. Print.

Charles, Christopher A. D. "Skin Bleaching, Self-Hate, and Black Identity in Jamaica." Journal of Black Studies 33.6 (2011): 711-728. Print.

---. "Skin Bleaching and the Prestige Complexion of Sexual Attraction." Sexuality \& Culture 15.4 (2011): 375-90. Web.

---. "Liberating Skin Bleachers: From Mental Pathology to Complex Personhood." JENdA: A Journal of Culture and African Women Studies 14 (2009). 86-100. Web.

Cooper, Carolyn. Noises in the Blood: Orality, Gender, and the "vulgar" Body of Jamaican Popular Culture. Durham: Duke University Press, 1995. Print.

---. Sound Clash: Jamaican Dancehall Culture at Large. New York: Palgrave Macmillan, 2004. Print. 
Edwards, Nadi. "Notes on the Age of Dis: Reading Kingston Through Agamben." Small Axe 25 (2008): 1-15. Web. 15 Mar. 2013.

Ellis, Nadia. "Out and Bad: Toward a Queer Performance Hermeneutic in Jamaican Dancehall." Small Axe 15.235 (2011): 7-23. Project MUSE. Web. 14 Dec. 2012

Foucault, Michael. History of Sexuality, Volume I: An Introduction. Trans. Robert Hurley. New York, NY: Random House, Inc., 1978. Print.

---. Power/Knowledge: Selected Interviews and Other Writings, 1972-1977, ed. Colin Gordon. New York: Pantheon, 1980.

Gilroy, Paul. The Black Atlantic: Modernity and Double Consciousness. Cambridge, Mass: Harvard University Press, 1993. Print.

Glenn, Evelyn Nakano. "Yearning For Lightness: Transnational Circuits in the Marketing and Consumption of Skin Lighteners." Gender and Society 22.3 (2008): 281302. JSTOR. Web.

Gray, Sherrian. "Trends in Urban Crime and Violence in Kingston, Jamaica." Unhabitat.org. United Nations, 2007. Web. 10 Apr. 2013. http://www.unhabitat.org/downloads/docs/grhs.2007.casestudy.crime.kingston.pd $\underline{f}$

Hall, Stuart, and Du Gay Paul. Questions of Cultural Identity. London: Sage, 1996. Print.

---. Representation: Cultural Representations and Signifying Practices. London: Sage in association with the Open University, 1997. Print.

Hall, Stuart, and Sut Jhally. Representation \& the Media. Northampton, MA: Media Education Foundation, 2002.

Hope, Donna P. Inna Di Dancehall: Popular Culture and the Politics of Identity in Jamaica. Mona, Jamaica: University of the West Indies Press, 2006. Print.

---. Man Vibes: Masculinities in the Jamaican Dancehall. Kingston: Ian Randle, 2010. Print.

---. Personal Interview. 5 July. 2013.

Howson, Alexandra. The Body in Society: An Introduction. Cambridge, UK: Polity, 2004. Print. 
Hunter, Margaret L. "Buying Racial Capital: Skin-Bleaching and Cosmetic Surgery in a Globalized World.” The Journal of Pan African Studies 4.4 (2011): 142-163. Web.

---. "The Persistent Problem of Colorism: Skin Tone, Status, and Inequality." Sociology Compass 1.1 (2007): 237-254. Web.

Ingram, Penelope. The Signifying Body: Toward an Ethics of Sexual and Racial Difference. Albany: State University of New York, 2008. Print.

Jackson Miller, Dionne. "All Angles: The Skin Bleaching Phenomenon.” All Angles. Television Jamaica. TVJ, Kingston, 19 June 2013. Television.

Jenks, Chris. Transgression. London: Routledge, 2003. Print.

Kartel, Vybz. "Pretty Like a Colouring Book." The Jamaica Journal 33.3 (2011): 24-29. Print.

Killer, Bounty. "Fed Up.” My Xperience. VP, 1996. CD.

Lesser, Beth. Dancehall: The Rise of Jamaican Dancehall Culture. London: Soul Jazz, 2008. Print.

"Let Them Kill Each Other: Public Security in Jamaica's Innercities." Amnesty International. Amnesty International, 01 Apr. 2008. Web. 7 Mar. 2013. $<$ http://www.amnesty.org/en/library/info/AMR38/001/2008/en>.

Mansfield, Nick. "Roland Barthes (1915-1980)." The Continuum Encyclopedia of Modern Criticism and Theory. Ed. Julian Wolfreys, Ruth Robbins, Kenneth Womack, and Kara Kalenius. New York: Continuum, 2002. 257-65. Print.

Patterson, Ebony G. www.ebonygpatterson.com. N.p., n.d. Web. May 17, 2013. http://ebonygpatterson.com/.

---. "Fashion Ova' Style: Beauty, Gender \& Masculinity." YoutTube. YouTube, 02 Apr. 2011. Web. 11 July 2013.

---. Swag-Swag Krew. 2012. Out and Bad.

---. Untitled III. 2007. Gangstas For Life. Creative Caribbean Network. Web. 14 June 2013.

Pitts, Victoria L. In The Flesh: The Cultural Politics of Body Modification. New York: Palgrave Macmillan, 2003. Print. 
Pratt, Mary Louise. "Arts of the Contact Zone." Profession (1991): 33-40. JSTOR. Web. 17 Oct. 2013.

Shilling, Chris. The Body and Social Theory. 2nd ed. London: Sage Publications, 2003. Print.

Stanley-Niaah, Sonjah Nadine. Dancehall: From Slave Ship to Ghetto. Ottawa: University of Ottawa, 2010. Print.

Stolzoff, Norman C. Wake the Town \& Tell the People: Dancehall Culture in Jamaica. Durham, N.C: Duke University Press, 2000. Print.

Sullivan, Nikki. A Critical Introduction to Queer Theory. New York: New York University Press, 2003. Print.

Thomas, Deborah A. Modern Blackness: Nationalism, Globalization, and the Politics of Culture in Jamaica. Durham: Duke University Press, 2004. Print.

Wolfreys, Julian. Transgression: Identity, Space, Time. Houndmills, Basingstoke, Hampshire: Palgrave Macmillan, 2008. Print. 